\title{
Functional and Neuroreceptor Imaging of the Brain in Bicuculline-Induced Dystonic Rats
}

\author{
QingGeLeTu, ${ }^{1,2}$ Yukihisa Suzuki, ${ }^{1,2}$ Motohiro Kiyosawa, ${ }^{1,2}$ KIICHi Ishiwata ${ }^{2}$ and \\ Manabu Mochizuki ${ }^{1}$
}

${ }^{1}$ Department of Ophthalmology and Visual Science, Tokyo Medical and Dental University, Tokyo, Japan
${ }^{2}$ Positron Medical Center, Tokyo Metropolitan Institute of Gerontology, Tokyo, Japan

Dystonia is an involuntary movement disorder dominated by sustained muscle contractions that frequently cause twisting, repetitive movements, and postural changes. The purpose of this study was to determine the mechanism causing dystonia. We therefore employed a rat model of dystonia, which was induced by injecting (-)-bicuculine methiodide (BM), a gamma-aminobutyric acid $A\left(G A B A_{A}\right)$ receptor antagonist, stereotaxically into the ventrolateral thalamic nuclei. Cerebral glucose metabolism reflecting cerebral activities and densities of central benzodiazepine and adenosine $A_{1}$ receptors that play an inhibitory role in neural excitation were evaluated in the brain by ex vivo autoradiography using appropriate ${ }^{14} \mathrm{C} /{ }^{18} \mathrm{~F}$ - or ${ }^{11} \mathrm{C}$ labeled tracers. The dystonic signs were accompanied by increased glucose metabolism in the thalamus, substantia nigra, globus pallidus, and striatum. However, central benzodiazepine receptor density was not altered, and adenosine $A_{1}$ receptor density was reduced in the hippocampus. These results indicate the activation of a basal ganglia-thalamo-cortical motor circuit, which consists of the thalamus, substantia nigra, globus pallidus, and striatum. In this context, the activation of the above circuit has been reported in human dystonia patients. The decreased adenosine $A_{1}$ receptor density in the hippocampus might be related to a transient hippocampal dysfunction due to an acute type of dystonia. In conclusion, we have succeeded in generating a rat model of dystonia, and observed the activation of the basal ganglia-thalamo-cortical motor circuit that is related to dystonia. —— adenosine $A_{1}$ receptor; bicuculline methiodide; central benzodiazepine receptor density; cerebral glucose metabolism; dystonia.

Tohoku J. Exp. Med., 2009, 217 (4), 313-320. (C) 2009 Tohoku University Medical Press

Dystonia is an involuntary movement disorder dominated by sustained muscle contractions that frequently cause twisting, repetitive movements, and postural changes (Fahn 1988). Focal dystonias include blepharospasms, writer's cramp, and spasmodic torticollis, and there are many clinical reports on these disorders. The glucose metabolism, reflecting cerebral activities, of human subjects with various disorders can be measured by positron emission tomography (PET) using 2- $\left[{ }^{18} \mathrm{~F}\right]$ fluorodeoxyglucose $\left(\left[{ }^{18} \mathrm{~F}\right] \mathrm{FDG}\right)$ (Phelps et al. 1979). This method is based on the deoxyglucose method (Sokoloff et al. 1977). PET studies have shown increased glucose metabolism in the thalamus (Esmaeli-Gutstein et al. 1999; Suzuki et al. 2007), cerebellum (Hutchinson et al. 2000), and pons (Suzuki et al. 2007) in patients with blepharospasm compared with healthy subjects. These findings demonstrated that hyperactivity of the basal ganglia circuit and/or cerebellar circuit might be the cause of dystonia.

In a study on neuroreceptors by PET using an appropriate radioligand, Perlmutter et al. (1997) reported a decrease in the density of dopamine $\mathrm{D}_{2}$-like receptors in the putamen of patients with essential blepharospasm and hand dystonia. Recently, Horie et al. (2009) also found decreased dopamine $\mathrm{D}_{2}$ receptors in the entire striatal region of patients with essential blepharospasm. On the other hand, Nobrega et al. (2005) observed that the adenosine $A_{1}$ receptor density in the dystonic brain is reduced in $\mathrm{dt}(\mathrm{sz})$-mutant.

It has been hypothesized that dystonia is a primary disorder of the sensory system involving the GABA-ergic transmission pathway (Hallett 1995). Several lines of evidence have suggested that altered GABA-ergic inhibition may play an important role in the pathophysiology of dystonia. For example, animal studies have shown that a unilateral injection of (-)-bicuculline methiodide (BM), a GABA antagonist, into the striatum of cats (Yoshida et al. 1991; Yamada et al. 1995) or thalamus of monkeys (Guehl et al. 2000; Macia et al. 2002) induced contralateral dystonia. However, there has not been a study that examined changes of the $\mathrm{GABA}_{\mathrm{A}}$-central benzodiazepine receptor complex or adenosine $A_{1}$ receptor density in non-hereditary dystonic

Received January 14, 2009; revision accepted for publication March 5, 2009.

Correspondence: Motohiro Kiyosawa, M.D., Ph.D., Positron Medical Center, Tokyo Metropolitan Institute of Gerontology, 35-2

Sakaecho, Itabashi, Tokyo, Japan.

e-mail: m.kiyosawa.oph@tmd.ac.jp 
brains.

Thus, the purpose of this study was to investigate the pathophysiology of dystonia. To accomplish this, we investigated the alterations in the cerebral glucose metabolism and central benzodiazepine and adenosine $\mathrm{A}_{1}$ receptors in a $\mathrm{BM}$-induced dystonia model in rats by ex vivo autoradiography. The cerebral glucose metabolism was evaluated by the uptake of $\left[{ }^{14} \mathrm{C}\right]$ deoxyglucose $\left(\left[{ }^{14} \mathrm{C}\right] \mathrm{DG}\right)$ or $\left[{ }^{18} \mathrm{~F}\right] \mathrm{FDG}$, and the central benzodiazepine and adenosine $\mathrm{A}_{1}$ receptors were evaluated by the uptake of $\left[{ }^{11} \mathrm{C}\right]$ flumazenil and $\left[{ }^{11} \mathrm{C}\right] 8$ dicyclopropylmethyl-1-methyl-3-propylxanthine $\left(\left[{ }^{11} \mathrm{C}\right] \mathrm{MPDX}\right)$, respectively. The selective binding of these radioligands for the respective receptors has been verified, and the uptake of the radioligands reflects the receptor densities (Wang et al. 2003).

\section{Materials ANd Methods}

Eight-week-old, male Wistar rats were obtained from Tokyo Laboratory Animals Company (Tokyo, Japan). Ketamine was purchased from Sankyo (Tokyo, Japan). BM was purchased from Sigma (Steinheim, Germany), and $\left[{ }^{14} \mathrm{C}\right] \mathrm{DG}(1.66-2.22 \mathrm{GBq} / \mathrm{mmol})$ was purchased from American Radiolabeled Chemicals (Saint Louis, MO). $\left[{ }^{18} \mathrm{~F}\right] \mathrm{FDG},\left[{ }^{11} \mathrm{C}\right]$ flumazenil (41-158 TBq/mmol) and $\left[{ }^{11} \mathrm{C}\right] \mathrm{MPDX}$ (43-270 $\mathrm{TBq} / \mathrm{mmol}$ ) were prepared in our laboratory (Wang et al. 2003).

\section{(-)-Bicuculine methiodide-induced dystonia model}

The rats were housed in an air- and light-controlled environment $\left(22^{\circ} \mathrm{C}, 12\right.$-hour light and 12-hour dark) with free access to food and water. The study was conducted in accordance with the Association for Research in Vision and Ophthalmology's Resolution on the Use of Animals in Research, and the procedures were approved by the Animal Care and Use Committee of Tokyo Metropolitan Institute of Gerontology.

The method of creating an animal model of contralateral dystonia in monkeys (Guehl et al. 2000; Macia et al. 2002) and cats (Yoshida et al. 1991; Yamada et al. 1995) were applied to rats. Rats were anesthetized with an intraperitoneal injection of ketamine $(100 \mathrm{mg} / \mathrm{kg})$ and fixed in a stereotaxic apparatus (Narishige, Tokyo, Japan). The cranium was exposed, and two small burr holes were made at coordinates of AP $2.2 \mathrm{~mm}$ and L $1.7 \mathrm{~mm}$ or R $1.7 \mathrm{~mm}$ from the bregma. The holes were drilled through the cranium with the dura preserved in order to inject physiological saline with or without BM into the ventrolateral thalamus nucleus on one side (Guehl et al. 2000). The BM was dissolved in physiological saline, and $2 \mu \mathrm{l}(1-20 \mu \mathrm{g})$ solution was injected into one ventrolateral thalamus nucleus at coordinates AP 2.2 $\mathrm{mm}, \mathrm{L} 1.7 \mathrm{~mm}$, and Z $6.0 \mathrm{~mm}$ or at AP $2.2 \mathrm{~mm}, \mathrm{R} 1.7 \mathrm{~mm}$, and Z 6.0 $\mathrm{mm}$ from the bregma. The injections were made with a microinjection pump (CMA/100, Stockholm, Sweden) for 4 min through a microinjection cannula (0.15-mm inner diameter, 0.35 outer diameter) (Eicom, Kyoto, Japan). The needle was kept in place for $2 \mathrm{~min}$ after the injection had been completed to allow the BM to diffuse into the surrounding tissue. Physiological saline $(2 \mu \mathrm{l})$ was injected into the contralateral ventrolateral thalamus nucleus in the same way. The numbers of rats used and the injected dose of BM were 2 with $1 \mu \mathrm{g}, 4$ with $2 \mu \mathrm{g}$, 11 with $7 \mu \mathrm{g}, 10$ with $10 \mu \mathrm{g}$, and 10 with $20 \mu \mathrm{g}$. After the injection of $\mathrm{BM}$, the rats were left from the stereotaxic frame and placed in a large cage. They were then monitored with a video camera for three hours and their behavior was evaluated. At low does of 1-2 $\mu \mathrm{g}$, the rat's head sometimes turned toward the side contralateral to side of the BM injection for $<60 \mathrm{~min}$. With a dose of $7 \mu \mathrm{g}$, most rats periodically showed this head turning behavior, and then twisting movement for 70 to $160 \mathrm{~min}$. These behaviors were similar to those observed in a cat model (Yoshida et al. 1991) and a hamster model of dystonia (Nobrega et al. 2005). At 10 and $20 \mu \mathrm{g}$, many rats showed convulsion and violent running, and five of the 20 rats died within $90 \mathrm{~min}$ after injection of BM. Based on these preliminary behavioral findings, we selected to use the rats injected with $7 \mu \mathrm{g}$ of $\mathrm{MB}$ for the following experiments.

\section{Ex vivo Autoradiography}

Three groups of rats were used in this study. One group of rats received $7 \mu \mathrm{g} \mathrm{BM}$ (BM group) in one of the ventrolateral thalamus nucleus with physiological saline $(2 \mu 1)$ in the contralateral side as described above. We selected 42 rats that showed the head-turning toward the side contralateral to that of the BM injection and then twisting movement at 60 min after the injection of BM. The second group was the sham-operated rats (sham-treated group; $n=36$ ), in which physiological saline $(2 \mu 1)$ was injected into one of the ventrolateral thalamus nucleus as described, and the contralateral side was not touched. In this group, the effects of surgery and injection of physiological saline was evaluated in comparison with normal brain without any surgery or injections. The third group of normal rats that did not received any surgery or injections (untreated group, $n=18$ ). This group was used to investigate whether lateral differences are present for glucose metabolism and benzodiazepine and adenosine $A_{1}$ receptors in the normal rat brain.

Ex vivo autoradiography was carried out on the BM group ( $n=$ 6 to 10 each) and the sham-treated group $(n=6$ each) at one hour or one day after the injection of BM or physiological saline (Wang et al, 2005). To evaluate the glucose metabolism, $\left[{ }^{14} \mathrm{C}\right] \mathrm{DG}(3 \mathrm{MBq} / \mathrm{kg}$ ) was injected into the tail vein $15 \mathrm{~min}$ after the $\mathrm{BM}$ or physiological saline. In the rats studied one day after the BM injection, the $\left[{ }^{18} \mathrm{~F}\right] \mathrm{FDG}(5-7$ $\mathrm{MBq} / \mathrm{kg}$ ) or $\left[{ }^{14} \mathrm{C}\right] \mathrm{DG}$ was injected into the tail vein 24 hours after the $\mathrm{BM}$ injection. All of the rats were killed $45 \mathrm{~min}$ after the injection of the tracer.

In the studies of the benzodiazepine and adenosine $\mathrm{A}_{1}$ receptors, $\left[{ }^{11} \mathrm{C}\right]$ flumazenil or $\left[{ }^{11} \mathrm{C}\right] \mathrm{MPDX}(1 \mathrm{GBq} / \mathrm{kg})$ was injected into the tail vein 30 min or 1 day after the injection of $\mathrm{BM}(n=5$ to 7$)$. The rats were killed $15 \mathrm{~min}$ after the injection of the tracer.

In 22 rats, a double tracer autoradiographic method (Wang et al, 2003) was used. $\left[{ }^{14} \mathrm{C}\right] \mathrm{DG}$ was injected into the tail vein, and $30 \mathrm{~min}$ later $\left[{ }^{11} \mathrm{C}\right]$ flumazenil was injected. The rats were then killed $15 \mathrm{~min}$ later. In the normal group, rats were killed 45 min after the injection of $\left[{ }^{14} \mathrm{C}\right] \mathrm{DG}(3 \mathrm{MBq} / \mathrm{kg})$ or $15 \mathrm{~min}$ after the injection of $\left[{ }^{11} \mathrm{C}\right]$ flumazenil or $\left[{ }^{11} \mathrm{C}\right] \operatorname{MPDX}(1 \mathrm{GBq} / \mathrm{kg})$ ( $n=6$ for each).

For all groups, the brain was rapidly dissected, frozen, and cut coronally into $20 \mu \mathrm{m}$ thick sections using a cryotome at $-15^{\circ} \mathrm{C}$ (Bright Instrument, Huntingdon, UK). The brain sections were mounted on glass slides, dried on a hot plate at $60^{\circ} \mathrm{C}$, and apposed to a storage phosphor screen (Phosphor Imager SI system, Molecular Dynamics, Sunnyvale, $\mathrm{CA}$ ). The exposure times required to demonstrate the distribution of ${ }^{11} \mathrm{C},{ }^{18} \mathrm{~F}$, and ${ }^{14} \mathrm{C}$ were two, four, and 96 hours, respectively. For double tracer autoradiography, the ${ }^{11} \mathrm{C}$ images were obtained by a 2 hours exposure, and after the complete decay-out of ${ }^{11} \mathrm{C}$, the ${ }^{14} \mathrm{C}$ images were obtained by a 72 hours exposure. 


\section{Data Analysis}

Regions of interest (ROIs) were marked on the superficial layers of the anterior cingulate area, primary somatosensory area, supplemental somatosensory area, striatum, globus pallidus, substanita nigra, thalamus, anterior pretectal nucleus, anterior hypothalamus, posterior hypothalamus, medial septal nucleus, and nucleus of the vertical limb of the diagonal band, medial geniculate nucleus, the CA1, CA2, and $\mathrm{CA} 3$ regions of the hippocampus, and dentate gyrus. These ROIs were determined from the histological sections that were stained with cresyl violet to identify the structures and from a rat brain atlas (Swanson 1996). The density of radioactivity in the ROIs was measured.

The ratio of radioactivity on the side injected with $\mathrm{BM}$ to that on the contralateral side injected with physiological saline (BM/C ratio) was calculated for each region to detect the differential changes in the uptake of each tracer (Wang et al, 2005). For the sham-treated group, the ratio of radioactivity on the side injected with physiological saline to that on the normal side $(\mathrm{C} / \mathrm{N}$ ratio) was calculated for each region, and for untreated group, the ratio of radioactivity in the right side to that in the left side ( $\mathrm{R} / \mathrm{L}$ ratio) was calculated. In addition to the comparison of both sides to detect the bilateral changes, we evaluated the uptake ratios of each region to the visual cortex as a reference region in the three groups.

Student's $t$ tests were used to analyze the significance of all of the $\mathrm{BM} / \mathrm{C}, \mathrm{C} / \mathrm{N}$, and $\mathrm{R} / \mathrm{L}$ ratios for each region using Stat View (Abacus Concepts Inc, Berkeley, CA, 1992). Kruskal-Wallis tests were used to analyze the data of the uptake ratios of each region to the visual cortex for the three groups by the SPSS (SPSS Japan, Tokyo, Japan) program.

\section{RESULTS}

Representative autoradiograms of $\left[{ }^{14} \mathrm{C}\right] \mathrm{DG}$, $\left[{ }^{11} \mathrm{C}\right]$ flumazenil, and $\left[{ }^{11} \mathrm{C}\right] \mathrm{MPDX}$ are shown in Figures. 1, 2, and 3 , respectively. The images of the three tracers in the brain of a rat in the sham-treated group at both one hour and one day after the injections were very similar to those in untreated group. No lateral difference in the ratio of tracer uptake ( $\mathrm{C} / \mathrm{N}$ and $\mathrm{R} / \mathrm{L}$ ratios) was found in all ROIs investigated for the three tracers between the sham-treated and untreated groups (data not shown).

The cerebral glucose metabolism in the striatum, globus pallidus, CA3, thalamus, substanita nigra, medial septal nucleus and nucleus of the vertical limb of the diagonal band, anterior hypothalamus, posterior hypothalamus, and anterior pretectal nucleus was significantly higher on the BM-injected side than that on the contralateral side at one hour (Table 1, Fig. 1). The cerebral glucose metabolism on both sides of the striatum, globus pallidus, CA1, CA2, CA3 of hippocampus and dentate gyrus, medial septal nucleus and nucleus of the vertical limb of the diagonal band, anterior hypothalamus, posterior hypothalamus, anterior pretectal nucleus, and BM injected side of the thalamus and sub-

TABLE 1. Uptake ratios of (-)-bicuculline methiodide (BM)-injected side to saline-injected side and relative uptake after intravenous injection of $\left[{ }^{14} \mathrm{C}\right] \mathrm{DG}$ or $\left[{ }^{18} \mathrm{~F}\right] \mathrm{FDG}$ into the BM-injected rats.

\begin{tabular}{|c|c|c|c|c|c|}
\hline & \multicolumn{4}{|c|}{ BM-group } & \multirow[t]{2}{*}{ Untreated } \\
\hline & \multicolumn{2}{|c|}{$\mathrm{BM} / \mathrm{C}$ ratio* } & \multicolumn{2}{|c|}{ Relative uptake** } & \\
\hline & $\begin{array}{l}<1 \text { hour } \\
(n=10)\end{array}$ & $\begin{array}{l}\text { Day 1 } \\
(n=7)\end{array}$ & $\begin{array}{l}\text { BM side } \\
<1 \text { hour } \\
(n=10)\end{array}$ & $\begin{array}{l}\text { Saline side } \\
<1 \text { hour } \\
(n=10)\end{array}$ & $\begin{array}{c}\text { Mean of both side } \\
<1 \text { hour } \\
(n=6)\end{array}$ \\
\hline Anterior cingulated area (AC) & $1.07 \pm 0.17$ & $0.94 \pm 0.07$ & $1.23 \pm 0.43$ & $1.05 \pm 0.36$ & $0.93 \pm 0.13$ \\
\hline Primary somatosensory area (SSp) & $1.08 \pm 0.19$ & $1.01 \pm 0.07$ & $0.94 \pm 0.20$ & $0.80 \pm 0.17$ & $0.88 \pm 0.05$ \\
\hline Supplemental somatosensory area (SSs) & $1.08 \pm 0.20$ & $0.99 \pm 0.12$ & $0.88 \pm 0.20$ & $0.76 \pm 0.16$ & $0.93 \pm 0.08$ \\
\hline Striatum $(\mathrm{St})$ & $1.10 \pm 0.10^{\mathrm{a}}$ & $1.02 \pm 0.04$ & $1.62 \pm 0.26^{\mathrm{b}}$ & $1.38 \pm 0.22^{\mathrm{a}}$ & $1.04 \pm 0.11$ \\
\hline Globus pallidus (GP) & $1.51 \pm 0.38^{\mathrm{b}}$ & $1.08 \pm 0.11$ & $1.46 \pm 0.25^{\mathrm{b}}$ & $0.93 \pm 0.18^{\mathrm{a}}$ & $0.69 \pm 0.04$ \\
\hline CA1 of hippocampus & $1.08 \pm 0.08$ & $0.96 \pm 0.11$ & $1.32 \pm 0.17^{\mathrm{a}}$ & $1.19 \pm 0.19^{\mathrm{a}}$ & $0.80 \pm 0.07$ \\
\hline CA2 of hippocampus & $1.09 \pm 0.12$ & $1.01 \pm 0.09$ & $1.41 \pm 0.15^{\mathrm{a}}$ & $1.24 \pm 0.26^{\mathrm{a}}$ & $0.82 \pm 0.07$ \\
\hline CA3 of hippocampus & $1.21 \pm 0.13^{\mathrm{a}}$ & $1.04 \pm 0.08$ & $1.06 \pm 0.22^{\mathrm{a}}$ & $0.93 \pm 0.21^{\mathrm{a}}$ & $0.66 \pm 0.04$ \\
\hline Dentate gyrus (Dg) & $1.17 \pm 0.32$ & $1.05 \pm 0.09$ & $1.01 \pm 0.31^{\mathrm{a}}$ & $0.92 \pm 0.20^{\mathrm{a}}$ & $0.67 \pm 0.08$ \\
\hline Thalamus (Th) & $1.14 \pm 0.11^{\mathrm{b}}$ & $0.98 \pm 0.06$ & $1.45 \pm 0.29^{\mathrm{a}}$ & $1.19 \pm 0.30$ & $1.06 \pm 0.10$ \\
\hline Substantia nigra (SN) & $1.54 \pm 0.32^{\mathrm{b}}$ & $1.09 \pm 0.11$ & $1.10 \pm 0.26^{\mathrm{b}}$ & $0.71 \pm 0.22$ & $0.67 \pm 0.12$ \\
\hline $\begin{array}{l}\text { Medial septal nucleus and nucleus of the vertical } \\
\text { limb of the diagonal band (MV) }\end{array}$ & $1.23 \pm 0.13^{\mathrm{b}}$ & $1.00 \pm 0.06$ & $1.54 \pm 0.37^{b}$ & $1.23 \pm 0.38^{\mathrm{a}}$ & $0.82 \pm 0.11$ \\
\hline Anterior hypothalamus $(\mathrm{AH})$ & $1.37 \pm 0.18^{\mathrm{b}}$ & $1.03 \pm 0.08$ & $1.47 \pm 0.51^{\mathrm{b}}$ & $1.04 \pm 0.33^{\mathrm{a}}$ & $0.67 \pm 0.05$ \\
\hline Posterior hypothalamus (PH) & $1.30 \pm 0.17^{\mathrm{b}}$ & $1.04 \pm 0.07$ & $1.52 \pm 0.28^{\mathrm{b}}$ & $1.15 \pm 0.29^{b}$ & $0.80 \pm 0.05$ \\
\hline Anterior pretecteal nucleus (APN) & $1.36 \pm 0.14^{\mathrm{b}}$ & $0.99 \pm 0.04$ & $1.88 \pm 0.33^{\mathrm{b}}$ & $1.34 \pm 0.36^{\mathrm{a}}$ & $1.05 \pm 0.05$ \\
\hline Medial geniculate nucleus (MG) & $1.04 \pm 0.06$ & $1.01 \pm 0.14$ & $0.69 \pm 0.09^{\mathrm{a}}$ & $0.64 \pm 0.11^{\mathrm{a}}$ & $1.03 \pm 0.23$ \\
\hline
\end{tabular}

*t-test $; \mathrm{a} ; P<0.01, \mathrm{~b} ; P<0.005$.

Result of one hour was obtained by $\left[{ }^{14} \mathrm{C}\right] \mathrm{DG}$, whereas result of one day was obtained by injection of $\left[{ }^{18} \mathrm{~F}\right] \mathrm{FDG}$.

**Kruskal-Wallis test (visual cortex as reference); a; $P<0.01$, b; $P<0.005$. 
Untreated

\section{$\mathrm{BM}$ injection}

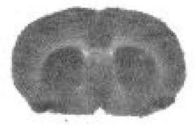

Sham-treated
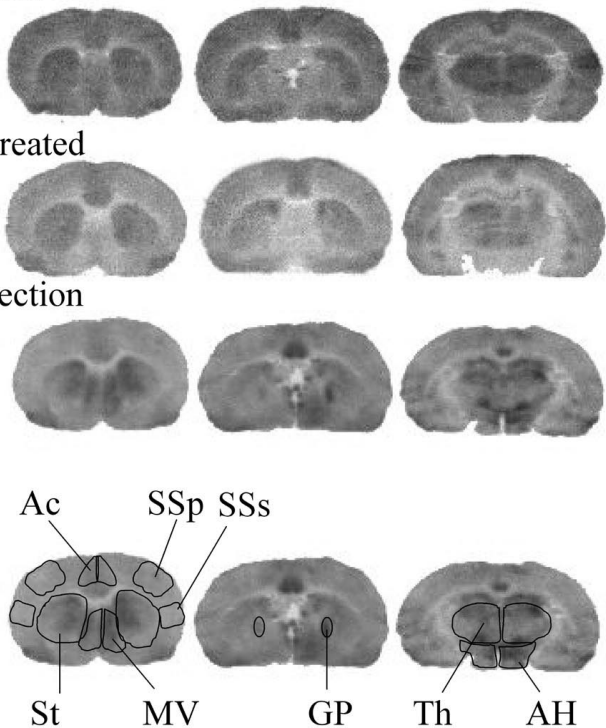
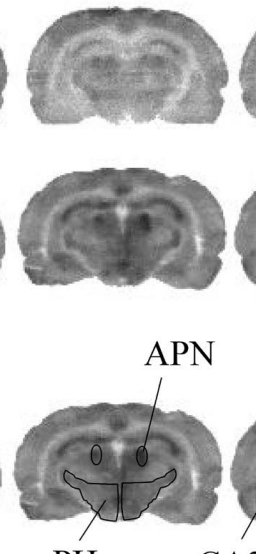

$\mathrm{PH}$

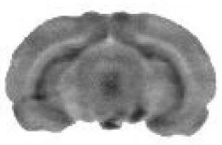

$\mathrm{R}$
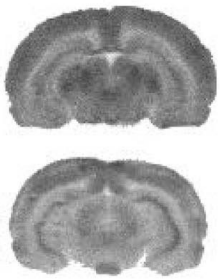

Dg $\quad$ CA1

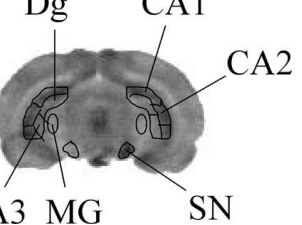

Fig. 1. Autoradiograms of $\left[{ }^{14} \mathrm{C}\right] \mathrm{DG}$ uptake in the rat brain.

Representative autoradiograms of $\left[{ }^{14} \mathrm{C}\right] \mathrm{DG}$ uptake in brain sections of untreated (top row) and sham-treated (second row), 1 hour after an injection of (-)-bicuculline methiodide (BM) into right side of the rat brain (third row). Regions of interests are placed on the BM-injection images and shown in the bottom row. Abbreviations are shown in Table 1. R mark indicates right side.

Untreated

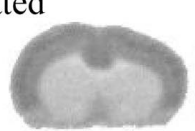

Sham-treated

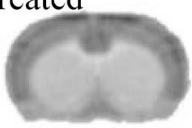

BM injection
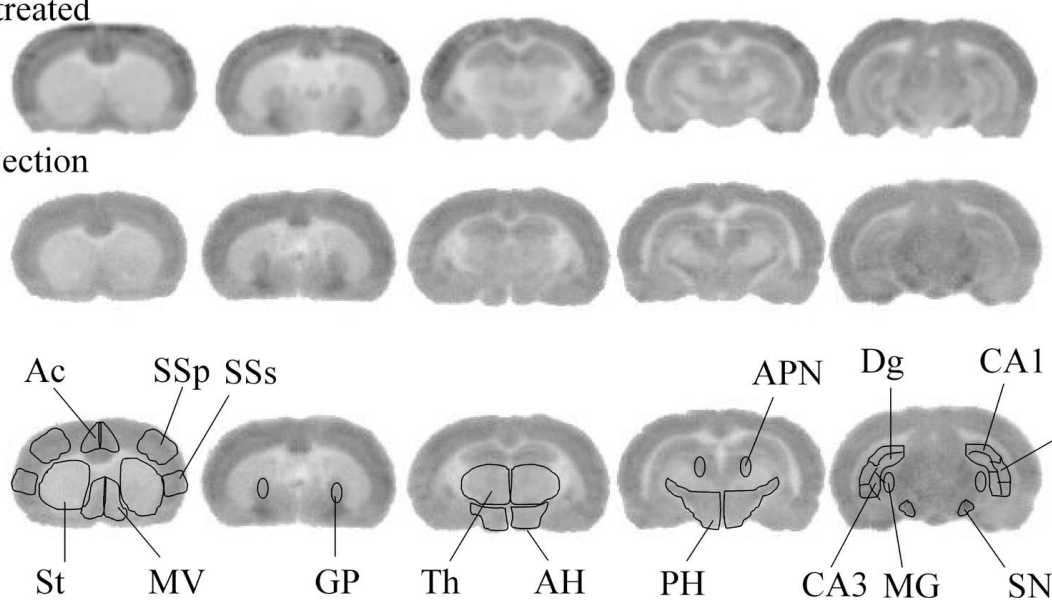

$\mathrm{R}$
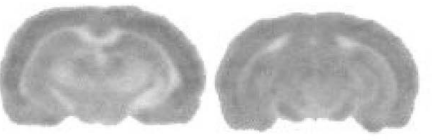

pSs

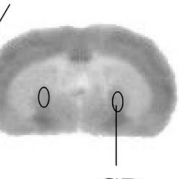

GP
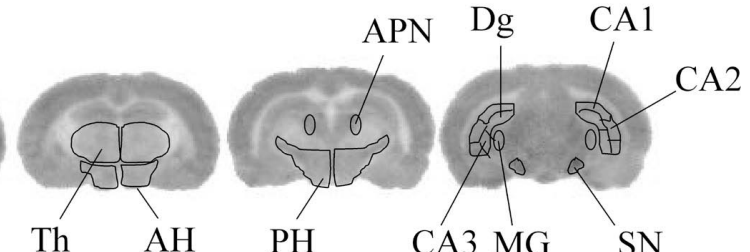

Fig. 2. Autoradiograms of $\left[{ }^{11} \mathrm{C}\right]$ flumazenil binding in the rat brain.

Representative autoradiograms of $\left[{ }^{11} \mathrm{C}\right]$ flumazenil binding in brain section of untreated (top row) and sham-treated (second row), 30 to 45 min after the injection of (-)-bicuculline methiodide (BM) into right side of the rat brain (third row). BM injection images were obtained from the same animal shown in Fig. 1 with the double tracer technique. Regions of interests are placed on the BM injection images and shown in the bottom row.

stanita nigra was significantly higher than that in the untreated group at one hour. However, the relative uptake on both sides of the medial geniculate nucleus decreased at one hour after the injection of BM (Table 1). One day after the injection of BM, no significant differences of glucose metabolism were observed in the $\mathrm{BM} / \mathrm{C}$ ratios, i.e. relative uptake on each side (Table 1).

In the autoradiograms of $\left[{ }^{11} \mathrm{C}\right]$ flumazenil, no significant differences were found between the BM-group and the sham-treated and untreated groups (Fig. 2). The BM/C ratios at one hour or one day after the treatment are summarized in Table 2. The uptake ratio of $\left[{ }^{11} \mathrm{C}\right] \mathrm{MPDX}$ decreased 
Untreated
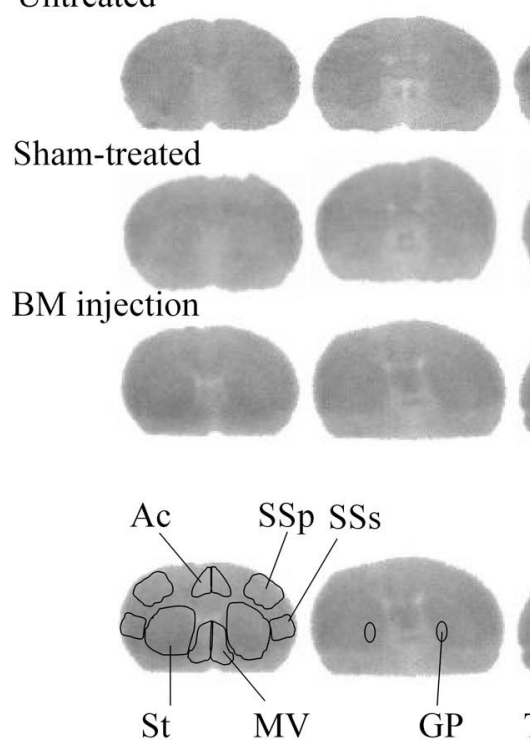
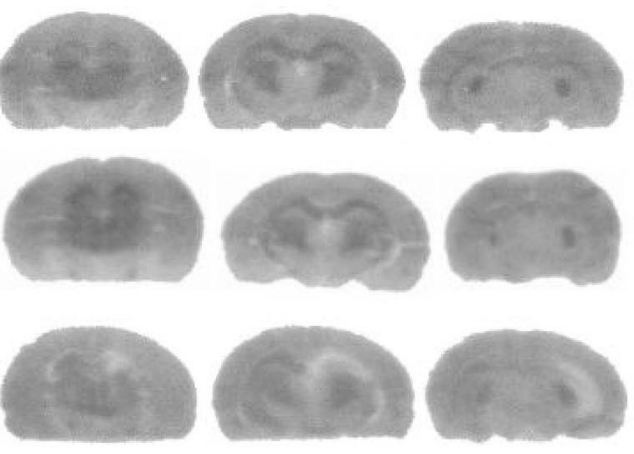

R

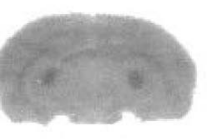

政 
Yamada et al. 1995). Most rats given $7 \mu \mathrm{g}$ of BM showed a head-turning toward the side contralateral to that of the BM injection and then twisting movements. Because these behaviors were similar to those observed in the cat model (Yoshida et al. 1991) and a dystonic hamster model (Nobrega et al. 2005), we used these rats in this study. It was noted that dystonic behaviors disappeared within 3 hours after the injection of BM. BM has also been used to induce a convulsive model in rats. However, the administration route, dose of BM, and the brain regions injected were different from that used in our dystonia model (Ingvar and Siesjö 1983; Miller and Ferrendelli 1990; Handforth et al. 1994; Inglefield and Kellogg 1994).

We found that glucose metabolism was increased in global regions of the brain but decreased only in the medial geniculate nucleus immediately after the injection of BM. These changes were transient and disappeared one day later. We also found that the binding of $\left[{ }^{11} \mathrm{C}\right]$ flumazenil to benzodiazepine receptors was not changed and that of $\left[{ }^{11} \mathrm{C}\right] \mathrm{MPDX}$ to adenosine $\mathrm{A}_{1}$ receptors was decreased in the hippocampus within one hour after the injection of BM. These behavioral and autoradiographic findings suggest that our rat model is a transient dystonia model.

\section{Regional changes in $\left[{ }^{14} \mathrm{C}\right] D G$ uptake during dystonia}

The glucose metabolism evaluated by the uptake of $\left[{ }^{14} \mathrm{C}\right] \mathrm{DG}$ reflects the cerebral activity. Immediately after the unilateral $\mathrm{BM}$ injection, an increased uptake of $\left[{ }^{14} \mathrm{C}\right] \mathrm{DG}$ was found on both sides of the striatum, globus pallidus, CA1, CA2, CA3 of hippocampus and dentate gyrus, medial septal nucleus and nucleus of the vertical limb of the diagonal band, anterior hypothalamus, posterior hypothalamus, and anterior pretectal nucleus, but decreased in the medial geniculate nucleus bilaterally. The glucose metabolism in the thalamus and substanita nigra was increased only on the side of the BM injection.

The results of functional imaging studies are often interpreted by using anatomical models of informational flow in the basal ganglia-thalamo-cortical motor circuit (Tempel and Perlmutter 1993). A modified drawing of the basal ganglia-thalamo-cortical motor circuit is shown in Fig. 4 (Horie et al. 2009). The $\mathrm{GABA}_{\mathrm{A}}$ receptors in the thalamus were blocked by the BM injected into the ventrolateral thalamus nucleus, and it might be expected that the suppressive effects of GABA would be decreased and the neural activity increased in the thalamus (Macia et al. 2002). In this circuit model, the activation in the thalamus would activate the supplemental somatosensory area, primary somatosensory area, and striatum (Vitek 2002). On the other hand, the activity in the hypothalamus, internal globus pallidus, and substanita nigra would be expected to decrease (Vitek 2002). In the chronic type of dystonia, earlier clinical data showed activation on the contralateral side of the primary somatosensory area, striatum, and thalamus by PET (Odergren et al. 1998) and functional MRI (Preibisch et al. 2001).

Deep brain stimulation of the internal globus pallidus is an established treatment for dystonia (Ostrem and Starr 2008), and activation of this area was observed after the globus pallidus stimulation treatments in humans (Detante et al. 2004). The results of the deep brain stimulation treatments may indicate hypoactivity in the internal globus pallidus in the chronic type of dystonia. However in this study, the duration of the dystonic postural changes was very short ( $<1$ hour), and most areas in the circuit were activated bilaterally even though BM was injected into only one thalamus and the dystonic posture was almost over the entire body. Clinically, it has been observed that this circuit was activated bilaterally in generalized dystonia (Eidelberg et al. 1998;1995). Galardi et al. observed hypermetabolism bilat-

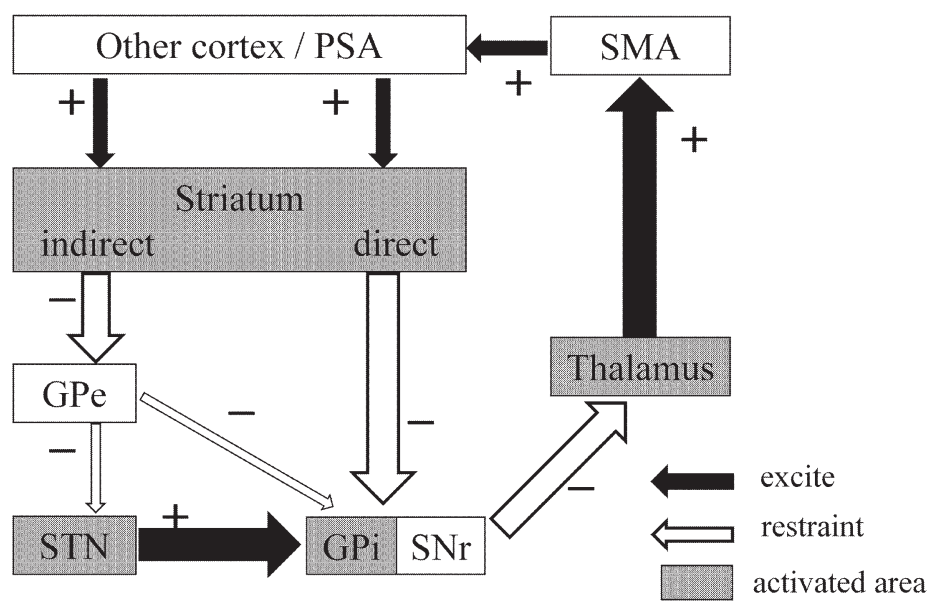

Fig. 4. Altered basal ganglia-thalamo-cortical motor circuit after bicuculline methiodide injection.

In the present study, we observed glucose hypermetabolism in the thalamus, striatum, globus pallidus, and subthalamic nucleus after bicuculline injection in the thalamus. The routes guessed to have strengthened were shown by bold arrow. PSA; primary somatosebnsory area, GPe; globus pallidus externa, STN; subthalamic nucleus, GPi; globus pallidus interna, SNr; substantia nigra reticulate, and SMA; supprimentary motor area. Modified from Horie at al. 2008. 
erally in the striatum, thalamus, and anterior cingulate area in patients with spasmodic torticollis using PET (Galardi et al. 1996). Spasmodic torticollis is a focal dystonia, but the cerebral glucose metabolism is similar to that of generalized dystonia (Evinger 2005). These observations suggest that a circuit is activated bilaterally in certain types of dystonia that also influence the contralateral side of the body.

Odergren et al. (1998) observed an increase in blood flow, an alternative index of the cerebral activity, in the hippocampus in writers with writer's cramp using PET. However, there is no report that has described an obvious relationship between dystonia and the hippocampus, although there are many studies that show a relationship between the hippocampus and epilepsy. Thus, Mirrione et al. (2006) observed a significant increase in the glucose metabolism in the hippocampus and insignificant hypermetabolism in the thalamus and striatum by PET in a mouse model of epilepsy. These findings would suggest that epileptic seizures are related to abnormal activity of the basal gangliathalamo-cortical motor circuit (Raggenbass and Bertrand 2002; Degos et al. 2008). From our observations in this rat model of dystonia, an acute type of dystonia might be generated by the activation of circuits which resemble the circuits that lead to epileptic seizures.

\section{No regional changes in central benzodiazepin receptor density in experimental dystonia}

Several lines of evidence have suggested that altered GABA-ergic inhibition may play an important role in the pathophysiological mechanism of dystonia. GABA is a major inhibitory neurotransmitter in the mammalian brain, and it is plausible that the loss of GABA-ergic function can lead to disinhibition of the somatosensory system. Levy and Hallett (2002) observed reduced levels of GABA in the sensorimotor cortex and lentiform nuclei of patients with writer's cramp using MR spectroscopy. However in our study, we did not find any changes in the central benzodiazepine receptor density in the BM-induced rat model of dystonia.

The changes in the density of the central benzodiazepine receptors might be chronic changes. In animal models, an up-regulation of central benzodiazepine receptors was detected in kittens after 1-2 weeks in ischemic lesion of the brain (Zepeda et al. 2004), and flurazepam and muscimol treatments caused a down-regulation of the central benzodiazepine receptors following 2-4 weeks in the rat brain (Klein and Harris 1996). These observations suggest that the density of central benzodiazepine receptors might not have been changed in our rat model because the duration of the dystonia was very short.

\section{Regional changes in adenosine $A_{1}$ receptor densities in experimental dystonia}

We observed that the $\left[{ }^{11} \mathrm{C}\right]$ MPDX binding in the CA1, CA2, CA3 of hippocampus and dentate gyrus was immediately reduced but returned to normal by the following day.
Adenosine is present in large areas of in the mammalian brain and is an endogenous modulator with anticonvulsive and neuroprotective activity (Fukumitsu et al. 2005; Pignataro et al. 2007). It has been reported that adenosine receptor agonists improve dystonia, and antagonists aggravate dystonia (Pignataro et al. 2007). Nobrega et al. (2005) evaluated the binding of $\left[{ }^{3} \mathrm{H}\right] 8$-Cyclopentyl-1,3-dipropylxanthine $\left.\left({ }^{3} \mathrm{H}\right] \mathrm{DPCPX}\right)$ to adenosine $\mathrm{A}_{1}$ receptors in the brain of dystonic mutant hamsters. They observed that under normal resting conditions, mutant hamsters showed a decrease in adenosine $\mathrm{A}_{1}$ receptors compared with controls. Under stressful conditions, the adenosine $A_{1}$ receptors were increased in almost all brain regions in both controls and dystonic hamsters. However, our result showed that binding of $\left[{ }^{11} \mathrm{C}\right] \mathrm{MPDX}$ to adenosine $\mathrm{A}_{1}$ receptors was low in the hippocampus in the dystonic stage. There are two possible explanations for these contradictory findings. One possibility is that the reaction of the binding of $\left[{ }^{11} \mathrm{C}\right] \mathrm{MPDX}$ to adenosine $\mathrm{A}_{1}$ receptor may be different in non-hereditary dystonic brain and dystonic mutant brain. As mentioned, binding of $\left[{ }^{11} \mathrm{C}\right] \mathrm{MPDX}$ to adenosine $\mathrm{A}_{1}$ receptors in the dystonic mutant brain was different from that of normal brain (Nobrega et al. 2005). A second possibility is that BMtreatment and dystonic seizure might cause transient hippocampal dysfunction and transient alterations in the binding of $\left[{ }^{11} \mathrm{C}\right] \mathrm{MPDX}$ to the adenosine $\mathrm{A}_{1}$ receptors. It has been reported that seizures cause neuronal damage and dysfunction in the hippocampus (Abdelmalik et al. 2007).

\section{CONClusions}

The cerebral glucose metabolism is altered in a BMinduced acute type of a rat dystonia model. This suggests that the activities of the basal ganglia-thalamo-cortical motor circuit are altered in this rat model of dystonia.

\section{References}

Abdelmalik, P.A., Shannon, P., Yiu, A., Liang, P., Adamchik, Y., Weisspapir, M., Samoilova, M., Burnham, W.M. \& Carlen, P.L. (2007) Hypoglycemic seizures during transient hypoglycemia exacerbate hippocampal dysfunction. Neurobiol. Dis., 26, 646-660.

Degos, B., Deniau, J.M., Le Cam, J., Mailly, P. \& Maurice, N. (2008) Evidence for a direct subthalamo-cortical loop circuit in the rat. Eur. J. Neurosci., 27, 2599-2610.

Detante, O., Vercueil, L., Thobois, S., Broussolle, E., Costes, N., Lavenne, F., Chabardes, S., Lebars, D., Vidailhet, M., Benabid, AL. \& Pollak, P. (2004) Globus pallidus internus stimulation in primary generalized dystonia: $\mathrm{a}_{2}{ }^{15} \mathrm{O}$ PET study. Brain, 127, 1899-1908.

Eidelberg, D., Moeller, J.R., Antonini, A., Kazumata, K., Nakamura, T., Dhawan, V., Spetsieris, P., deLeon, D., Bressman, S.B. \& Fahn, S. (1998) Functional brain networks in DYT1 dystonia. Ann. Neurol., 44, 303-312.

Eidelberg, D., Moeller, J.R., Ishikawa, T., Dhawan, V., Spetsieris, P., Przedborski, S. \& Fahn, S. (1995) The metabolic topography of idiopathic torsion dystonia. Brain, 118, 1473-1484.

Esmaeli-Gutstein, B., Nahmias, C., Thompson, M., Kazdan, M. \& Harvey, J. (1999) Positron emission tomography in patients with benign essential blepharospasm. Ophthal. Plast. Reconstr. Surg., 15, 23-27. 
Evinger, C. (2005) Animal models of focal dystonia. NeuroRx., 2, 513-524.

Fahn, S. (1988) Concept and classification of dystonia. Adv. Neurol., 50, 1-8.

Fukumitsu, N., Ishii, K., Kimura, Y., Oda, K., Sasaki, T., Mori, Y. \& Ishiwata, K. (2005) Adenosine $\mathrm{A}_{1}$ receptor mapping of the human brain by PET with 8-dicyclopropylmethyl-1- ${ }^{11} \mathrm{C}$-methyl-3-propylxanthine. J. Nucl. Med., 46, 32-37.

Galardi, G., Perani, D., Grassi, F., Bressi, S., Amadio, S., Antoni, M., Comi, G.C., Canal, N. \& Fazio, F. (1996) Basal ganglia and thalamo-cortical hypermetabolism in patients with spasmodic torticollis. Acta Neurol. Scand., 94, 172-176.

Guehl, D., Burbaud, P., Boraud, T. \& Bioulac, B. (2000) Bicuculline injections into the rostral and caudal motor thalamus of the monkey induce different types of dystonia. Eur. J. Neurosci., 12,1033-1037.

Hallett, M. (1995) Is dystonia a sensory disorder? Ann. Neurol., 38, 139-140.

Handforth, A., Finch, D.M., Peters, R., Tan, A.M. \& Treiman, D.M. (1994) Interictal spiking increases 2-deoxy[14C]glucose uptake and c-fos-like reactivity. Ann. Neurol., 35, 724-731.

Horie, C., Suzuki, Y., Kiyosawa, M., Mochizuki, M., Wakakura, M., Oda, K., Ishiwata, K. \& Ishii, K. (2009) Decreased dopamine $\mathrm{D}_{2}$ receptor binding in the essential blepharospasm. Acta Neurol. Scand., 119, 49-54.

Hutchinson, M., Nakamura, T., Moeller, J.R., Antonini, A., Belakhlef, A., Dhawan, V. \& Eidelberg, D. (2000) The metabolic topography of essential blepharospasm: a focal dystonia with general implications. Neurology, 55, 673-677.

Inglefield, J.R. \& Kellogg, C.K. (1994) Hypothalamic GABAA receptor blockade modulates cerebral cortical systems sensitive to acute stressors. Psychopharmacology, 116, 339345.

Ingvar, M. \& Siesjö, B.K. (1983) Local blood flow and glucose consumption in the rat brain during sustained bicucullineinduced seizures. Acta Neurol. Scand., 68,129-144.

Klein, R.L. \& Harris, R.A. (1996) Regulation of $\mathrm{GABA}_{\mathrm{A}}$ receptor structure and function by chronic drug treatments in vivo and with stably transfected cells. Jpn. J. Pharmacol., 70, 1-15.

Levy, L.M. \& Hallett, M. (2002) Impaired brain GABA in focal dystonia. Ann. Neurol., 51, 93-101.

Macia, F., Escola, L., Guehl, D., Michelet, T., Bioulac, B. \& Burbaud, P. (2002) Neuronal activity in the monkey motor thalamus during bicuculline-induced dystonia. Eur. J. Neurosci., 15, 1353-1362.

Miller, J.W. \& Ferrendelli, J.A. (1990) Characterization of GABAergic seizure regulation in the midline thalamus. Neuropharmacology, 29, 649-655.

Mirrione, M.M., Schiffer, W.K., Siddiq, M., Dewey, S.L. \& Tsirka, S.E. (2006) PET imaging of glucose metabolism in a mouse model of temporal lobe epilepsy. Synapse, 59, 119-121.

Nobrega, J.N., Barlow, K.L., Raymond, R. \& Richter, A. (2005) Decreased adenosine receptor binding in dystonic brains of the dt(sz) mutant. Neuroscience, 134, 33-38.

Odergren, T., Stone-Elander, S. \& Ingvar, M. (1998) Cerebral and cerebellar activation in correlation to the action-induced dystonia in writer's cramp. Mov. Disord., 13, 497-508.
Ostrem, J.L. \& Starr, P.A. (2008) Treatment of dystonia with deep brain stimulation. Neurotherapeutics, 5, 320-330.

Perlmutter, J.S., Stambuk, M.K., Markham, J., Black, K.J., McGeeMinnich, L., Jankovic, J. \& Moerlein, S.M. (1997) Decreased $\left[{ }^{18} \mathrm{~F}\right]$ spiperone binding in putamen in idiopathic focal dystonia. J. Neurosci., 17, 843-850.

Phelps, M.E., Huang, S.C., Hoffman, E.J., Selin, C., Sokoloff, L. \& Kuhl, D.E. (1979) Tomographic measurement of local cerebral glucose metabolic rate in humans with ${ }^{18} \mathrm{~F}$-2-fluoro-2-deoxyD-glucose: validation of method. Ann. Neurol., 6, 371-388.

Pignataro, G., Simon, R.P. \& Boison, D. (2007) Transgenic overexpression of adenosine kinase aggravates cell death in ischemia. J. Cereb. Blood Flow Metab., 27, 1-5.

Preibisch, C., Berg, D., Hofmann, E., Solymosi, L. \& Naumann, M. (2001) Cerebral activation patterns in patients with writer's cramp: a functional magnetic resonance imaging study. $J$. Neurol., 248, 10-17.

Raggenbass, M. \& Bertrand, D. (2002) Nicotinic receptors in circuit excitability and epilepsy. J. Neurobiol., 53, 580-589.

Sokoloff, L., Reivich, M., Kennedy, C., Des Rosiers, M.H., Patlak, C.S., Pettigrew, K.D., Sakurada, O. \& Shinohara, M. (1977) The $\left[{ }^{14} \mathrm{C}\right]$ deoxyglucose method for the measurement of local cerebral glucose utilization: theory, procedure, and normal values in the conscious and anesthetized albino rat. J. Neurochem., 28, 897-916.

Suzuki, Y., Mizoguchi, S., Kiyosawa, M., Mochizuki, M., Ishiwata, K., Wakakura, M. \& Ishii, K. (2007) Glucose hypermetabolism in the thalamus of patients with essential blepharospasm. J. Neurol., 254, 890-896.

Swanson, L.W. (1996) Brain maps: structure of the rat brain, 2nd ed., Elsevier Science Ltd, Amsterdam.

Tempel, L.W. \& Perlmutter, J.S. (1993) Abnormal cortical responses in patients with writer's cramp. Neurology, 43, 2252-2257.

Vitek, J.L. (2002) Pathophysiology of dystonia: A neuronal model. Mov. Disord., 17, S49-S62.

Wang, W.-F., Ishiwata, K., Kiyosawa, M., Shimada, J., Senda, M. \& Mochizuki, M. (2003) Adenosine $\mathrm{A}_{1}$ and benzodiazepine receptors and glucose metabolism in the visual structures of rats monocularly deprived by enucleation or eyelid suture at a sensitive period. Jpn. J. Ophthalmol., 47, 182-190.

Wang, W.-F., Kiyosawa, M., Ishiwata, K. \& Mochizuki, M. (2005) Glucose metabolism in the visual structures of rat monocularly deprived by eyelid suture after postnatal eye opening. Jpn.J. Ophthalmol., 49, 6-11.

Yamada, H., Fujimoto, K. \& Yoshida, M. (1995) Neuronal mechanism underlying dystonia induced by bicuculline injection into the putamen of the cat. Brain Res., 677, 333-336.

Yoshida, M., Nagatsuka, Y., Muramatsu, S. \& Niijima, K. (1991) Differential roles of the caudate nucleus and putamen in motor behavior of the cat as investigated by local injection of GABA antagonists. Neurosci. Res., 10, 34-51.

Zepeda, A., Sengpiel, F., Guagnelli, M.A., Vaca, L. \& Arias, C. (2004) Functional reorganization of visual cortical maps after focal ischemic lesions is accompanied by changes in expression of cytoskeletal proteins and NMDA and $\mathrm{GABA}_{\mathrm{A}}$ receptor subunits. J. Neurosci., 24, 1812-1821. 